\title{
Study of Structural Strength and Behavior of Concrete Filled Double Skin Columns
}

\author{
Aamir Hassan $^{\# 1}$, Ms.S.Sivakamasundari*2 ${ }^{2}$, \\ ${ }^{*}$ 'M Tech, student, Department of Civil Engineering SRM University Chennai, India \\ $*^{2}$ Assistant professor, Department of Civil Engineering SRM University Chennai, India
}

\begin{abstract}
Column is a major Axial load transferring Member in most of the structures. According to the revised seismic codes columns should be have better flexural strength in addition to the Axial load carrying capacity. It is been a major concern in construction industry in previous few years to increase the column strength. Concrete-Filled Double Skin Tubes (CFDST) is one of the latest innovations in Structural engineering

The CFDST members were first designed for vessels to resist extreme external pressure but due to its various advantages, it has got strong demand and strong potential for using it in bridges, flyovers and high rise buildings. In this study CFDST is analysed using ABAQUS/CAE 6.11-1 and experimentally tested for stress strain and axial shortening.
\end{abstract}

\section{Keywords-CFDST, ABAQUS.}

\section{INTRODUCTION}

The concept of CFDST has evolved from the use of hollow Steel tubular members. These members have long been used in offshore and inland construction however, local and global stability often prevent the steel tubular sections from attainment of their full plastic capacity. The possible means of improving the instability of these sections is using the infill in these members such as concrete filled tubes (CFT). This technique has been used in over last four decades and is still used in construction industry.

Advantages of sandwich construction over concrete filled tubular (CFT) sections includes, higher bending stiffness, avoids instability under external pressure, interaction of the three (steel tubes and concrete) components results in good local stability, increase in section modulus, enhances global stability, good for seismic retrofit, lighter weight, good damping characteristics and good cyclic performance

\section{CFDST}

Concrete-filled double skin steel tubular (CFDST) members are composite members which consist of an inner and outer steel skin with the annulus between the skins filled with concrete. The concrete is properly compacted and packed in-between the two steel surfaces. The interaction between the steel and concrete is due to the frictional resistance between steel and concrete.

\section{STEel TUBeS}

The inner and outer tube are made of a fabricated box section with yield strength of $415 \mathrm{kNm}$. The inner tube is provided as $30 \times 30 \mathrm{~mm}$ crossection with thickness $2 \mathrm{~mm}$, while as the outer tube is provided as $100 \times 100 \mathrm{~mm}$ crossection with thickness of $3 \mathrm{~mm}$. The stell tube test specimen are shown in figure 1 below.

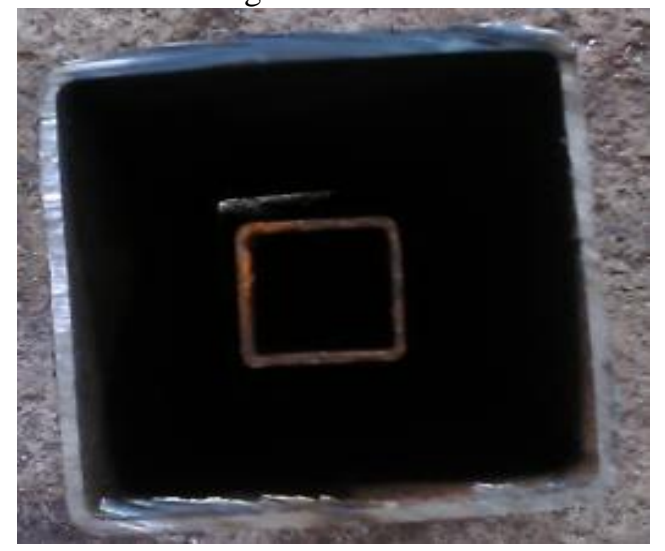

Fig 1: steel tubes

\section{Concrete}

Concrete is designed to have the maximum compressive sterength of $35 \mathrm{kN}$. The concrete is not provided with any admixtures to attain ultimate compressive strength. The cement used for this study is Portland Pozzolanic Cement is conforming to Indian Standard IS 12269 - 1987 of grade 53. The sand is used as fine aggregate and it is collected from nearby area. The sand has been sieved in $2.36 \mathrm{~mm}$ sieve. The Fine sieve size is used to increase the strength of the concrete. The coarse aggregate is choosen by shape as per IS 2386 (Part I) 1963, surface texture characteritics of aggregate is classified as in IS 383 - 1970. The aggregates used in the specimen are $10 \mathrm{~mm}$ seived. They are used for increased workabiltity and to attain high strength.

\section{MODELING}

The analysis of the CFDST is done using Abaqus/CAE 6.11-1 finite element software as shown in figure 2. The elements are modeled as C-0-C elements. C3D8 elements are used for modeling of concrete (i.e. 8 noded solid 3D elements). Outer tube Inner tube and plate are modeled using S4R (i.e. 4 noded shell elements).. Tie constraint is provided between concrete and steel .The Boundary conditions applied are as

i. For steel translational and rotational were restrained

ii. In concrete translational is restrained.

Finite element analysis of the CFDST is done with least possible no of elements. the stress, strain, and axial deformation is calculated simultaneously for each set of elements. The graphs are drawn for the conclusion of stress 
strain and axial deformation and the results are compared with the experimental results of CFDST columns. The load applied on the specimen is calculated by strength of material concept.

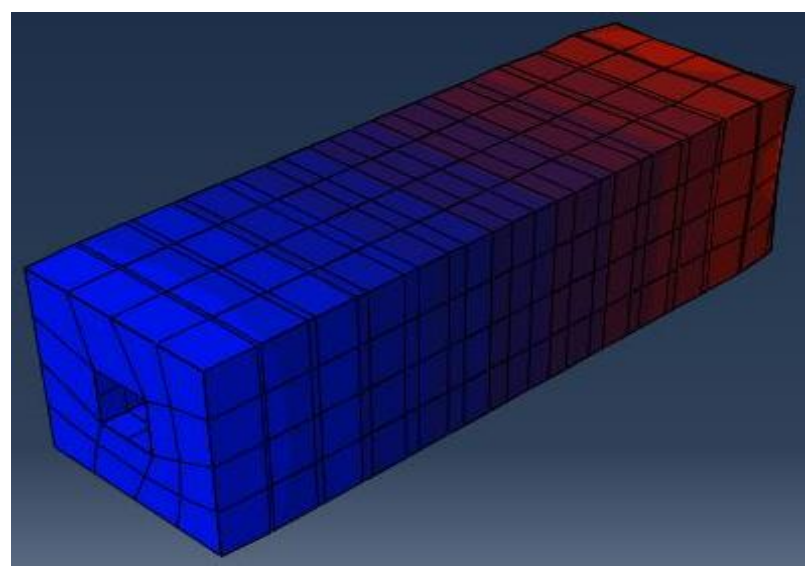

Fig 2: Abaqus model

\section{OBJECTIVE}

- The main aim of research is to study the structural integrity and strength of the CFDST.

- To study the failure mechanism in CFDST.

- To study the governing factors for the strength of the CFDST

\section{METHODOLOGY}

The procedure of the work involves detailed analytical and experimental investigation and the comparison between analytical and experimental results. The analytic study can be done by making use of a structural analysis software while as experimental investigation requires material and CFDST testing with following components:

i. Creating a computer model by making use of Abaqus/CAE 6.11-1

ii. Application of the loads.

iii. Carrying out analysis and evaluating the output of structural parameters.

iv. casting and testing of the CFDST

v. comparison of the analytic and experimental investigation results.

\section{Analytical Results}

The analysis of the CFDST is based upon the Finite element Method (F.E.M) approach. The number of the elements in outer tube, inner tube and concrete is simultaneously increased. The Axial shortening, stress and strain is calculated with increase in the number of the elements. The stress, strain and axial shortening of the $350 \mathrm{~mm}, 450 \mathrm{~mm}$ and $550 \mathrm{~mm}$ length CFDST column with respect to the number of the elements shown in table 1 , table 2 table 3 respectively.
Table 1: Analytic results of CFDST Column With $350 \mathrm{~mm}$ Length

\begin{tabular}{|c|c|c|c|c|}
\hline S.No. & $\begin{array}{c}\text { Number } \\
\text { of } \\
\text { elements }\end{array}$ & $\begin{array}{c}\text { Stress } \\
\text { N/mm2 }\end{array}$ & $\begin{array}{c}\text { Strain } \\
(\mathrm{e}-3)\end{array}$ & $\begin{array}{c}\text { Displacement } \\
(\mathrm{mm})\end{array}$ \\
\hline 1 & 19 & 2.42 & 2.185 & 4.427 \\
\hline 2 & 30 & 2.43 & 3.745 & 4.408 \\
\hline 3 & 47 & 2.44 & 3.707 & 4.424 \\
\hline 4 & 61 & 2.45 & 3.74 & 4.425 \\
\hline 5 & 78 & 2.65 & 4.36 & 5.06 \\
\hline 6 & 131 & 2.89 & 4.523 & 5.163 \\
\hline 7 & 220 & 2.96 & 4.528 & 5.377 \\
\hline 8 & 287 & 3.15 & 4.718 & 5.375 \\
\hline 9 & 516 & 3.51 & 5.22 & 5.613 \\
\hline 10 & 634 & 3.33 & 5.232 & 5.624 \\
\hline 11 & 1020 & 3.18 & 8.766 & 5.44 \\
\hline 12 & 1074 & 3.18 & 9.52 & $5 . .44$ \\
\hline 13 & 1344 & 3.14 & 7.246 & 5.36 \\
\hline 14 & 1920 & 3.16 & 8.65 & 5.02 \\
\hline 15 & 2112 & 3.02 & 9.979 & 5.177 \\
\hline
\end{tabular}

Table 2: Analytic results of CFDST Column With $450 \mathrm{~mm}$ Length

\begin{tabular}{|c|c|c|c|c|}
\hline S.No & $\begin{array}{c}\text { Number } \\
\text { of } \\
\text { elements }\end{array}$ & $\begin{array}{c}\text { Stress } \\
\mathrm{N} / \mathrm{mm}^{2}\end{array}$ & $\begin{array}{c}\text { Strain } \\
\mathrm{e}-3\end{array}$ & $\begin{array}{c}\text { Displacement } \\
(\mathrm{mm})\end{array}$ \\
\hline 1 & 19 & 2.436 & 4.316 & 5.66 \\
\hline 2 & 63 & 2.471 & 3.955 & 5.65 \\
\hline 3 & 94 & 2.616 & 4.517 & 6.07 \\
\hline 4 & 157 & 2.849 & 4.46 & 6.327 \\
\hline 5 & 220 & 2.896 & 4.242 & 6.62 \\
\hline 6 & 267 & 3.091 & 4.321 & 6.64 \\
\hline 7 & 430 & 3.242 & 5.024 & 6.69 \\
\hline 8 & 624 & 3.583 & 5.799 & 7.332 \\
\hline 9 & 711 & 3.511 & 5.11 & 6.887 \\
\hline 10 & 807 & 3.332 & 5.2 & 6.887 \\
\hline 11 & 861 & 3.318 & 5.227 & 6.887 \\
\hline 12 & 1176 & 3.32 & 5.547 & 6.889 \\
\hline
\end{tabular}

Table 3: Analytic results of CFDST Column With $550 \mathrm{~mm}$ Length

\begin{tabular}{|c|c|c|c|c|}
\hline S.No. & $\begin{array}{c}\text { Number } \\
\text { of } \\
\text { elements }\end{array}$ & $\begin{array}{c}\text { Stress } \\
\text { N/mm2 }\end{array}$ & $\begin{array}{c}\text { Strain } \\
(\mathrm{e}-3)\end{array}$ & $\begin{array}{c}\text { Displacement } \\
(\mathrm{mm})\end{array}$ \\
\hline 1 & 4 & 4 & 2.446 & 4.535 \\
\hline 2 & 8 & 8 & 2.462 & 4.22 \\
\hline 3 & 12 & 12 & 2.475 & 4.22 \\
\hline
\end{tabular}


International Journal of Engineering Trends and Technology (IJETT) - Volume 18 Number 6 - Dec 2014

\begin{tabular}{|c|c|c|c|c|}
4 & 24 & 24 & 2.607 & 4.443 \\
\hline 5 & 44 & 44 & 2.775 & 4.415 \\
\hline 6 & 72 & 72 & 2.786 & 4.009 \\
\hline 7 & 96 & 96 & 3.069 & 4.673 \\
\hline 8 & 104 & 104 & 3.157 & 4.796 \\
\hline 9 & 224 & 224 & 3.066 & 4.669 \\
\hline 10 & 296 & 296 & 3.526 & 5.49 \\
\hline 11 & 352 & 352 & 3.328 & 5.261 \\
\hline 12 & 552 & 552 & 3.167 & 8.603 \\
\hline 13 & 732 & 732 & 3.221 & 8.171 \\
\hline 14 & 1040 & 1040 & 3.078 & 9.115 \\
\hline
\end{tabular}

\section{CFDST TESTING}

CFDST were testing in column testing machine and load was applied with the increment of $10 \mathrm{kN} / \mathrm{s}$. the specimen was provided with steel plate of thickness $6 \mathrm{~mm}$ for the uniform distribution of the load. Figure 4 shows the column testing of the CFDST.

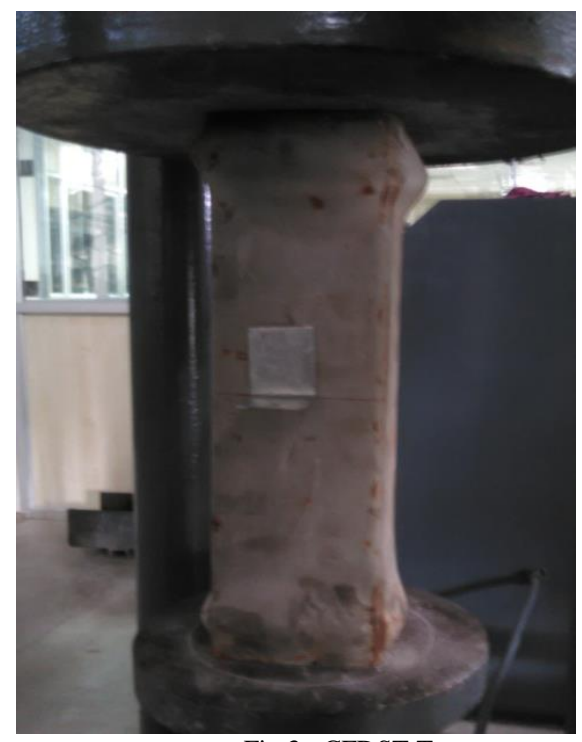

Fig 3: CFDST Test

The ultimate load and the maximum deflection in the specimen was recorded. The experimental test results are shown in table $4 \&$ table 5 .

Table 4 ultimate load carrying capacity of CFDST after 28 days

\begin{tabular}{|c|c|c|c|c|c|}
\hline \multirow{2}{*}{ Specimen } & \multirow{2}{*}{$\begin{array}{c}\text { Predicted / } \\
\text { Theoretical } \\
\text { load } \\
\text { carrying } \\
\text { capacity }\end{array}$} & \multicolumn{4}{|c|}{ Experimental value } \\
\hline & & $\begin{array}{c}\text { Trail } \\
1\end{array}$ & $\begin{array}{c}\text { Trail } \\
2\end{array}$ & $\begin{array}{c}\text { Trail } \\
3\end{array}$ & $\begin{array}{c}\text { Average } \\
\text { value }\end{array}$ \\
\hline $\begin{array}{c}\text { CFDST } \\
350 \mathrm{~mm} \mathrm{Ht}\end{array}$ & 857.10 & 910 & 890 & 870 & 890.00 \\
\hline
\end{tabular}

\begin{tabular}{|c|c|c|c|c|c|}
\hline $\begin{array}{c}\text { CFDST } \\
450 \mathrm{~mm} \mathrm{Ht}\end{array}$ & 857.10 & 820 & 870 & 820 & 836.67 \\
\hline $\begin{array}{c}\text { CFDST } \\
550 \mathrm{~mm} \mathrm{Ht}\end{array}$ & 857.10 & 610 & 670 & 660 & 646.67 \\
\hline
\end{tabular}

Table 4 ultimate load carrying capacity of CFDST after 28 days

\begin{tabular}{|c|c|c|c|c|c|}
\hline \multirow{2}{*}{ Specimen } & $\begin{array}{c}\text { Predicted / } \\
\text { Analytic } \\
\text { shortening }\end{array}$ & \multicolumn{4}{|c|}{ Experimental value } \\
\cline { 3 - 6 } & $\begin{array}{c}\text { Trail } \\
1\end{array}$ & $\begin{array}{c}\text { Trail } \\
2\end{array}$ & $\begin{array}{c}\text { Trail } \\
3\end{array}$ & $\begin{array}{c}\text { Average } \\
\text { value }\end{array}$ \\
\hline $\begin{array}{c}\text { CFDST } \\
\text { 350mm Ht }\end{array}$ & 5.44 & 4.4 & 4.9 & 4.2 & 4.50 \\
\hline $\begin{array}{c}\text { CFDST } \\
\text { 450mm Ht }\end{array}$ & 6.88 & 4.9 & 4.6 & 4.9 & 4.80 \\
\hline $\begin{array}{c}\text { CFDST } \\
\text { 550mm Ht }\end{array}$ & 7.80 & 4.6 & 5.8 & 4.6 & 5.00 \\
\hline
\end{tabular}

\section{RESUlt COMPARISON}

The comparison between the analytic and experimental results for ultimate load carrying capacity and axial shortening of the CFDST is shown in figure 4 and figure 5 respectively.

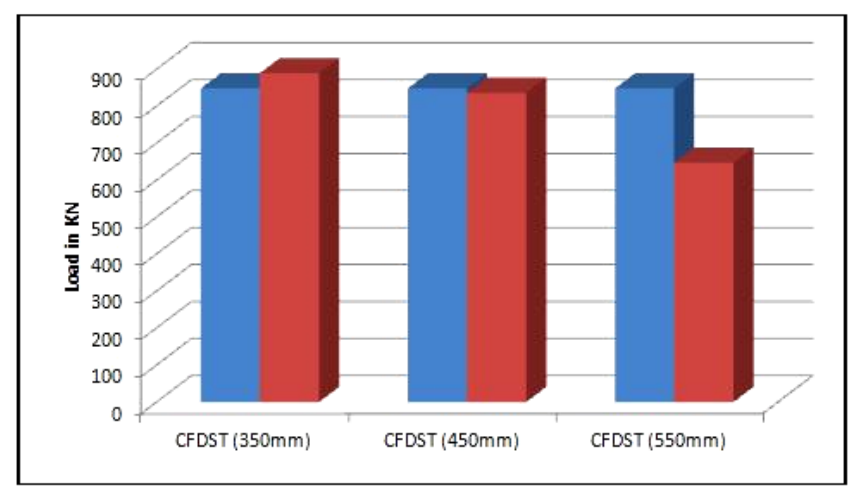

Fig. 4 Comparison Of Ultimate Load Carrying Capacity

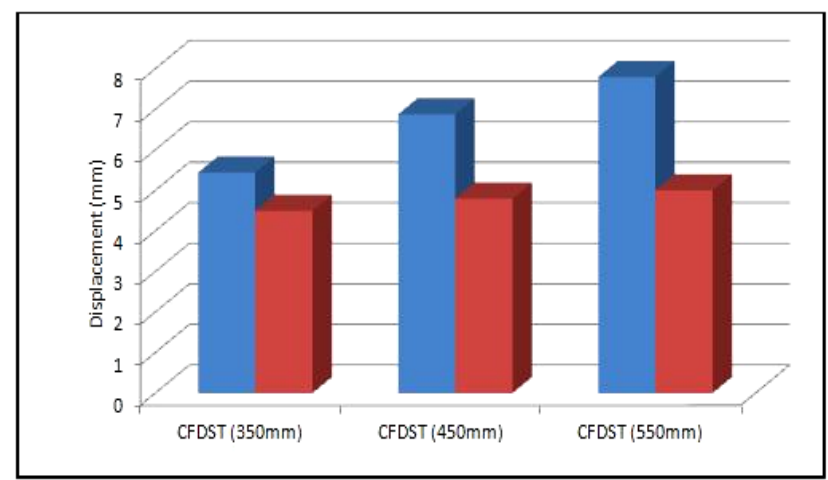

Fig. 4 Comparison Of Axial shortening 


\section{Conclusion}

The CFDST columns show substantial increase in axial load carrying capacity with less axial shortening. the effective composite action of the steel tubes and concrete increases the strength of the CFDST columns. The failure mechanism which is local buckling is favorable for construction industry. The results of Axial shortening, Stress And Strain are in acceptance with the experimental results, thus proper formulae can be adopted for future use of the CFDST columns in construction. The ductile failure mechanism of the column also makes it good for seismic construction and seismic retrofit.

\section{References}

[1] B. Burgan (1997). 'Technical steel research on Double skin composite construction for submerged tube tunnels European Commission". The guidelines for performance based seismic design of tall buildings, version 1.0, November 2010.

[2] C.X. Dong and J.C.M. Ho (2012). 'Concrete-filled Double-skin Tubular Columns with External Steel Rings'. Australian Earthquake Engineering Society 2012 Conference, Dec 7-9, Gold Coast, Qld.

[3] Elchalakani M. Xiao-Ling Zhao, Raphael Grzebieta (2002), "Tests on concrete filled double skin(CHS outer and SHS inner) composite short columns under axial compression". Elsevier ThinWalled Structures vol. 40 (2002) pp. 415-441.

[4] Hong Huanga, Lin-Hai Han, Zhong Tao, Xiao-Ling Zhao, (2009), "Analytical behavior of concrete-filled double skin steel tubular (CFDST) stub columns". Journal of Constructional Steel Research vol. 66 (2010) pp. 542_555.

[5] Hui Lu, Lin-Hai Han, Xiao-Ling Zhao, (2010) ,"Experimenta Fire performance of self-consolidating concrete filled double skin steel tubular columns". Fire Safety Journal vol. 45 (2010) pp. $106-115$.

[6] IS-456 2000 : Code of Practice for Plain and Reinforced Concrete

[7] IS-10262 2009: Guidelines for Concrete Mix Proportions.

[8] Lin-Hai Han, Zhong Tao, Hong Huang, Xiao-Ling Zhao, (2004) , "Concrete-filled double skin (SHS outer and CHS inner) steel tubular beam-columns". Elsevier Thin-Walled Structures vol. 42 (2004) pp. 1329-1355. 25

[9] Lin-Hai Han, Hong Huang, Xiao-Ling Zhao, (2008), "Analytical behavior of concrete-filled double skin steel tubular (CFDST) beam-columns under cyclic loading". Thin-Walled Structures vol. 47 (2009) pp. 668-680

[10] Lin-Hai Han, Zhong Tao, Fei Yu Liao, Yi Xu, (2010), "cyclic Performance of FRP concrete steel double skin tubular columns". Thin-Walled Structures vol. 48 (2010) pp. 430-439.

[11] T. Yu, Y.L. Wong, J.G. Teng, and S.L. Dong, (2007): "Behaviour of Hybrid FRP Concrete Steel Double Skin Tubular Columns". (ASCE)CC.1943-5614.0000331. American Society of Civil Engineers.

[12] Zhong Tao, Lin-Hai Han, Xiao-Ling Zhao, (2003), "Behaviour of concrete-filled double skin (CHS inner and CHS outer) steel tubular stub columns and beam-columns". Journal of Constructional Steel Research vol. 60 (2004) pp. 1129-1158.

[13] http://www.iitk.ac.in/nicee. 